\title{
Periodontal disease and atherosclerosis
}

\section{Doença periodontal e aterosclerose}

\author{
Jeferson Freitas Toregeani', Carlos Augusto Nassar', Krischina Aparecida Mendes Toregeani', \\ Patrícia Oehlmeyer Nassar ${ }^{1}$
}

\begin{abstract}
Atherosclerotic disease (AD) is one of the most important causes of morbidity and mortality in the world. It expresses inflammatory markers such as C-reactive protein (CRP) and can provoke arterial wall thickening, which can be evaluated using Doppler ultrasound. Risk factors associated with AD include diabetes mellitus, systemic arterial hypertension, dyslipidemia and smoking. More recently, periodontal disease (PD) has been identified as a factor related to $\mathrm{AD}$. Periodontal disease has a high prevalence in the global population and the inflammatory process and bacterial activity at the periodontium appear to increase the risk of AD. Encouraging good oral hygiene can reduce expression of inflammatory markers of $A D$. A review of literature on $P D, A D$ and inflammatory markers and the interrelationships between the two diseases was conducted using data published in articles indexed on the PUBMED, SCIELO and BIREME databases.
\end{abstract}

Keywords: periodontal disease; atherosclerosis; carotid intima-media thickness.

\begin{abstract}
Resumo
A doença aterosclerótica (DA) constitui uma das principais causas de morbimortalidade no mundo. A sua expressão laboral pode ser através de marcadores inflamatórios, como a proteína $C$ reativa (PCR) e/ou o espessamento da parede arterial, que pode ser analisado pela ultrassonografia com Doppler colorido. Os fatores de risco associados à DA são o diabetes mellitus, a hipertensão arterial sistêmica, a dislipidemia e o tabagismo. Mais recentemente, a doença periodontal (DP), que tem uma elevada prevalência na população mundial, tem sido considerada um fator relacionado ao desenvolvimento da DA, em que o processo inflamatório e a atividade bacteriana no periodonto parecem aumentar o risco para a DA. A motivação da higiene oral pode diminuir a expressão dos marcadores inflamatórios da DA. Com base em dados publicados em revistas eletrônicas e indexados pelos mecanismos de busca PUBMED, SCIELO e BIREME, foi realizada uma revisão de literatura sobre a DP e a DA, além dos marcadores inflamatórios expressos em ambas as doenças e suas possíveis inter-relações.
\end{abstract}

Palavras-chave: doença periodontal; aterosclerose; espessura íntima-média carotídea. 


\section{ATHEROSCLEROTIC DISEASE}

Atherosclerotic disease (AD) comprises a series of histopathological abnormalities that compromise the arterial circulatory system, obstructing the lumina of blood vessels. It has multifactorial etiology and a chronic nature and very often has early onset in people with risk factors such as dyslipidemia, diabetes mellitus and smoking. ${ }^{1}$ Examples of AD include the group of diseases known as cardiovascular diseases (CVDs), the most important of which are myocardial infarction secondary to obstruction of the coronary arteries, cerebral vascular accident secondary to obstruction of the carotid arteries and their branches, and peripheral arterial disease, which most often affects the lower limbs. ${ }^{2}$

Atherosclerotic disease is one of the principal causes of morbidity and mortality in the adult and elderly population. ${ }^{3}$ According to the World Health Organization (WHO), CVDs were responsible for $20 \%$ of all deaths worldwide in 1995 , passing the $50 \%$ point in some developing countries. In 1999 , CVDs were responsible for one third of deaths on Earth. In 2010, they were responsible for 33\% of all deaths in the world. ${ }^{4}$ According to the WHO 2013 annual report, ${ }^{5} 32 \%$ of deaths in the entire world were caused by CVDs.

In Brazil, CVD-related mortality in 2004 was one of the highest in Latin America, with 286 deaths per 100 thousand people. ${ }^{6}$ In 2006, 29\% of causes of death in Brazil were related to CVDs. In 2008, 37\% of deaths were caused by CVDs. ${ }^{5}$

With relation to public healthcare spending, hospital admissions on the Brazilian national health service because of CVDs are responsible for very heavy expenditure. In 2007, 27.4\% of admissions of people aged 60 years or older were caused by CVDs. ${ }^{7}$ In $2008,10 \%$ of admissions of people in all age groups were caused by CVDs with an estimated cost of 1.6 billion Reais. ${ }^{8}$ Low socioeconomic status has a negative influence and is associated with higher CVD prevalence. A study conducted by Schmidt et al. ${ }^{7}$ in Porto Alegre, Rio Grande do Sul, Brazil, found that CVD mortality between the ages of 45 and 64 was $163 \%$ higher in an underprivileged population living on the outskirts of the city.

\section{PATHOPHYSIOLOGY OF ATHEROSCLEROTIC DISEASE}

From the pathological point of view, AD is the result of changes to the permeability of vascular endothelium in the tunica intima, which allows lipids and inflammatory cells, precursors of atherosclerotic plaques, to enter the artery wall. ${ }^{9}$ Normally, low density lipoproteins (LDLs) are deposited in endothelial cells. These LDLs are hydrolyzed into phospholipids, triglycerides, proteins and cholesterol. After hydrolysis, certain receptors are expressed on the cellular membrane and other products, such as cholesterol, are utilized in reconstruction of the cell membrane..$^{10}$ In the presence of hypercholesterolemia, or in situations that aggravate deposition of LDLs, nitric oxide (NO) consumption in endothelial cells and free radical production are increased, leading to dysfunction of metabolism of fatty acids, apoproteins, lecithin and protein $\mathrm{G}$. The final result is endothelial incapacity to adequately respond to systemic aggressions..$^{10}$ Endothelial NO production is impaired because of reduced expression of NO synthetase, increased synthesis of nicotinamide adenine dinucleotide phosphate oxidase (NADPH oxidase) and increased expression of adhesion molecules, such as type 1 intercellular adhesion molecule (ICAM-1), endothelial selectin and type 1 vascular cell adhesion molecule (VCAM-1), with migration of monocytes to the artery wall and formation of foam cells, which are rich in fat, and gradual progression to atherosclerotic plaques. ${ }^{8,11}$

Atherosclerosis is a process that begins during childhood with the appearance of fatty streaks, which are precursor abnormalities of the atheromatous plaques that normally appear at more advanced ages. $^{12}$ The disease follows a varied course, with periods of quiescence interspersed with periods of rapid progression, developing throughout life, with deposition of lipids at the same time as the inflammatory process grows uncontrollably. Atherosclerotic plaques can progress to significant stenosis, after many years of silent development. ${ }^{9}$ In the final stages they can become unstable and progress to rupture, exposing the subendothelial layer, which contains lipids, collagen and elastin, and with the possibility of thrombus formation, which tends to be the final acute event in the majority of cases of obstructive AD. ${ }^{6,8,10}$

Symptoms vary in relation to the degree of narrowing of the artery lumen, the velocity of progression, the presence of collateral circulation and the metabolism of the organ involved, and may manifest as precordial pain (angina or acute myocardial infarction), in the case of coronary artery disease (CAD); neurological disorders such as aphasia, paresis, paralysis and amaurosis, in the case of cerebrovascular disease; and pain in the lower limbs (intermittent claudication, rest pain and 
gangrene), in the case of peripheral arterial disease (PAD). ${ }^{13,14}$

External factors, such as diet, smoking, physical exercise and medications (primarily statins and platelet antiaggregants) can all affect the course of $\mathrm{AD}$ and control risk factors, reducing adhesion molecule expression and improving endothelial response in patients with atherosclerosis. ${ }^{11}$

In view of the facts that $\mathrm{AD}$ is a progressive disease and that changing risk factors can decelerate its progression, mechanisms must be employed to identify people who are more susceptible and who have more serious forms of the disease. To achieve this objective, certain markers can be used to asses the risk of individuals who are still asymptomatic from a clinical point of view, but who will be more likely to develop CVDs.

\section{Markers of atherosclerotic disease}

Evaluation of AD can be accomplished by means of analysis of clinical, laboratory and radiological parameters. Detection of initial AD from a clinical point of view is unreliable, since clinical methods cannot detect early risk because symptoms generally emerge in cases in which more than $70 \%$ of the lumen is already obstructed..$^{15}$

Laboratory test options include assaying blood samples for plasma concentrations of LDL cholesterol, triglycerides, fasting glycemia, glycated hemoglobin and C-reactive protein (CRP), which are markers linked with $\mathrm{AD}$ progression. ${ }^{16}$

$\mathrm{C}$-reactive protein is an acute-phase protein belonging to the pentraxin family. ${ }^{17}$ It was discovered by Tillett and Francis. ${ }^{18}$ At the time, it was believed to be a pathogenic secretion. Its molecular weight is 25,106 Daltons and synthesis is coded by chromosome 1. It is found in the blood and is produced by the liver in response to proinflammatory cytokines released during any type of systemic inflammatory process. ${ }^{19}$ After tissue aggression, CRP concentrations increase rapidly within 2 hours and, after the inflammatory stimulus subsides, they return to normal levels within 18 hours. ${ }^{20}$ Balan $^{3}$ conducted a systematic review showing that CRP concentrations are higher in patients with ongoing inflammatory processes, such as periodontitis, and generally pass $2.1 \mathrm{mg} / \mathrm{L}$.

When CRP binds to phospholipids expressed on the cell surface it can stimulate endothelial, smooth muscle and inflammatory cells. Proliferation of smooth muscle cells can cause blood vessel thickening and increased macrophage activity can lead to formation of foam cells, which trigger the atherosclerotic process. Stimulation of endothelial cells can provoke expression of inflammatory receptors, as seen in Table 1. ${ }^{21,22}$ This protein also acts on bacteria and other pathogenic agents, binding to phosphocholine, thereby facilitating macrophagic phagocytosis. The complement system is responsible for the inflammatory process that breaks down cells and pathogens, destroying cell membranes by depositing proteins called opsonins. ${ }^{23}$

Several mediators regulate expression of CRP. Interleukin six (IL-6) is an important activator of CRP production. ${ }^{24}$ It is an immunomodulatory and proinflammatory cytokine and is primarily secreted by monocytes, macrophages and $\mathrm{T}$ lymphocytes that are activated at sites of inflammation. In addition to its proinflammatory activity, IL-6 also has procoagulatory effects that can aggravate the thrombotic manifestations of CVDs. ${ }^{25}$

Healthy people who have higher than normal CRP levels tend to have a higher incidence of CVDs. ${ }^{26}$ The association between elevated concentrations of acute phase proteins, including CRP, fibrinogen and serum amyloid type A, and the adhesion molecules ICAM1, E-Selectin and VCAM-1, is related to progression of atherosclerosis and the CVDs. ${ }^{8,11}$

The arterial system can be assessed using imaging methods including ultrasonography with color Doppler, computed tomography angiography and magnetic resonance angiography ${ }^{27}$ Since ultrasound is a more accessible and less expensive method, it has become the preferred method for screening and monitoring of AD. ${ }^{28}$

Color Doppler ultrasonography is a noninvasive examination that can aid in detection of the morphological changes that occur when arteries

Table 1. Biological activity of C-Reactive Protein ${ }^{24}$ (p. 544). Biological activity of C-Reactive Protein

Liver

Production of CRP

- Stimulation by inflammatory cytokines (IL-6)

Endothelial Cells

- Reduced nitric oxide production

- Increased Endothelin 1 production

- Expression of adhesion molecules (ICAM-1 and VCAM-1)

- Release of plasminogen activator inhibitor (PAI-1)

Smooth Muscle Cells

- Proliferation and migration of smooth muscle cells

- Production of Free Radicals

Monocytes and Macrophages

- Increased cholesterol uptake

- Expression of cytokines IL-1, IL-6 and TNF- $\alpha$

- Expression of MCP-1

- Expression of tissue factor

- Release of PAI-1 
are exposed to the factors that predispose to atherosclerosis, in addition to identifying abnormalities that are pathological per se, such as atherosclerotic plaques, calcifications, thromboses and aneurysms. ${ }^{28}$

Ultrasound is generated by a transducer made from crystals (ceramic or piezoelectric) that creates oscillatory mechanical waves with frequencies varying from 2 to $17 \mathrm{mHz}$. There is a hardware component that sends preprogrammed information to the crystals under the control of specially developed software. At the same time, ultrasound equipment is also capable of capturing the echoes generated when the ultrasound waves are reflected by tissues. Software then analyzes the waves and converts them into images. ${ }^{29,30}$

Radiofrequency is an oscillatory electrical wave in the range of $3 \mathrm{kHz}$ to $300 \mathrm{gHz}$. Either technique can be used to measure the thickness of the tunica intima and tunica media of the common carotid artery, to monitor intima-media thickening. Notwithstanding, radiofrequency offers slightly better precision because ultrasound interacts with tissues and can suffer alterations that depend on the properties of each organ analyzed, such as their density and reflection coefficient. Although there are minor differences between the techniques, both can be used to accurately evaluate intima-media thickness (IMT) (Figure 1)..$^{31-33}$

In a normal artery there are two layers with distinct acoustic impedances: the transition between blood and the tunica intima, and the transition between the tunica media and the adventitia. The distance between these two acoustic interfaces forms the intima-media complex (IMC). Intima-media thickening, which is usually of a diffuse nature, is one manifestation of $\mathrm{AD}$

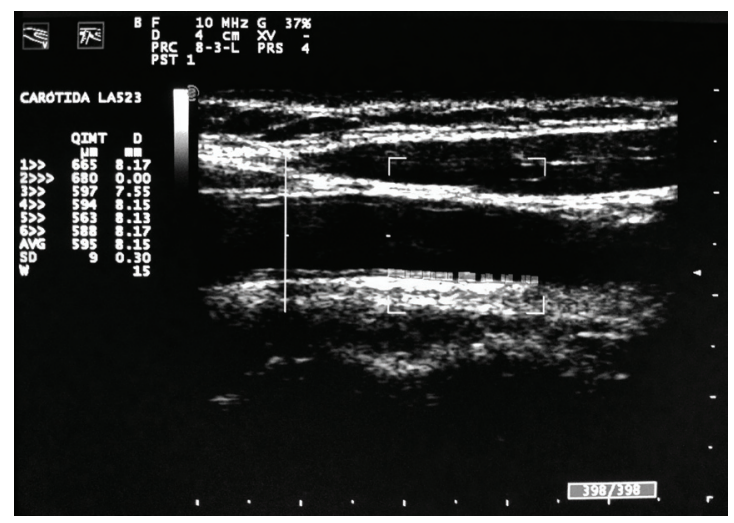

Figure 1. Image used to calculate myointimal thickness of the common carotid artery employing color ultrasonography equipment supplemented with radio frequency spectrum. and another is formation of atherosclerotic plaques, which are defined as focal structures that invade the arterial lumen by at least $0.5 \mathrm{~mm}$ or by $50 \%$ of the size of the adjacent IMC. Signs that can be detected using radiofrequency can be employed to measure the IMC of the common carotid artery, which is able to detect early variations in IMT that may be related to CVDs, and can also be used to monitor the success of treatment and reduction of risk factors for CVDs. ${ }^{33}$

The American Heart Association recommends measuring IMT to assess cardiovascular risk ${ }^{34}$ and the technique was standardized at the Mannheim consensus in Germany in 2004 and later revised in Brussels, in Belgium, in 2006. ${ }^{35}$ As recommended by the American Society for Echocardiography Report, IMT is measured in the common carotid artery. ${ }^{36,37}$

\section{Periodontal disease}

The teeth are rigid structures used to grind food, facilitating digestion in the stomach. They are made up of connective tissues and a mineral matrix and are inserted in the alveoli bones of the dental arches. Teeth are also formed of cementum, which is a rigid material, composed of $50 \%$ organic material, primarily collagen type I, and $50 \%$ apatite. Cementum covers the roots of teeth, and the fibers that form the periodontal ligament and provide support to the teeth inserted into the cementum. In addition to cementum, teeth also have a covering on their external portion with a porcelain-like appearance that is called enamel and is composed of $70 \%$ mineral matrix and $30 \%$ organic matrix and water. ${ }^{38}$

The base of each tooth has a covering that is constituted by differentiation of oral mucosa into three functional compartments: the gingival epithelium, the sulcular epithelium and the junctional epithelium. The junctional epithelium is the most important because it protects deep dental tissues and if it suffers inflammation, the structures that support the teeth may become exposed, which can lead to inflammatory and infectious processes and even result in loss of the tooth. ${ }^{38}$

Periodontal disease (PD) is a complex chronic inflammatory disease involving bacterial activity and resulting in destruction of the tissues that support the teeth. ${ }^{39}$ The most common clinical signs of periodontitis are gingival bleeding and edema. More advanced cases manifest with gingival recession, increased crevicular fluid, produced around the tooth, increased mobility of teeth, suppuration and, sometimes, even loss of the tooth. ${ }^{3,8}$

Poor oral hygiene remains the primary cause of $\mathrm{PD}$ and it is the greatest cause of tooth loss among 
people over the age of $40 . .^{40}$ According to the WHO, the severe form affects around 10 to $20 \%$ of all people worldwide..$^{40}$ Prevalence of the mild and moderate forms varies from 20 to $50 \%$ of the population and can be as high as $85 \%$ in elderly populations. ${ }^{3}$ Moderate and severe forms affect around 100 million people, which corresponds to $15 \%$ of adults aged 21 to 50 and $30 \%$ of adults over 50 years of age. ${ }^{8,11}$ The prevalence of gingivitis in the United States is $50 \%$ of adults and periodontitis affects $35 \%$ of the North-American population. ${ }^{9}$

In Brazil, oral health is not uniform and in less developed regions people who have lower levels of education and come from less privileged social strata are the most affected. Additionally, few regions in Brazil maintain constant and reliable records of oral health indicators.

\section{PATHOPHYSIOLOGY OF PERIODONTAL DISEASE}

Several microorganisms have been described as causing PD, particularly Porphyromonas gingivalis. Bacteria produce endotoxins in the form of lipopolysaccharides (LPS) capable of triggering release of several different proinflammatory cytokines that are involved in the immunopathology of periodontitis and also in systemic responses to oral inflammatory processes..$^{39}$ Examples include interleukin 1 beta (IL 1 $\beta$ ), IL-6, tumor necrosis factor alpha (TNF- $\alpha$ ), CRP and neutrophils. ${ }^{41,42}$

Chronic inflammation associated with bacterial plaque is predominantly caused by gram-negative bacteria. After the inflammatory stimulus there is increased production of prostaglandin E2 (PGE2) and of matrix metalloproteinases (MMP), which lead to extracellular destruction of the gingiva and the periodontal ligament, stimulating resorption of alveolar bone. ${ }^{8}$ Concurrent growth of anaerobic bacteria can promote formation of periodontal pockets. ${ }^{8}$

The inflammatory process at the periodontium leads to an increase in concentrations of CRP, and of other mediators such as fibrinogen, causing a systemic response. ${ }^{40}$ Periodontal disease is also capable of affecting the emergence and severity of certain systemic diseases, including CVDs. ${ }^{43}$

In addition to increased cytokine concentrations, MMP levels also rise. All of the MMPs are important in the immunoresponse, but MMP-8 is the only proteinase that is able to fragment types I and III collagen, which are important for maintaining the structure of teeth. Thus, the higher the concentration of MMP-8, the worse the prognosis of PD. There are also correlations between periodontitis severity and concentrations of MMP-13, MMP-3, MMP-2 and MMP- $1 .{ }^{3}$ The effect of bacterial proliferation and release of MMPs is activation of multiple cells, such as fibroblasts, keratinocytes, macrophages and endothelial cells. Bone resorption takes place as a result of fragmentation of the elements of the extracellular matrix by osteoclasts. ${ }^{3}$

The inflammatory process is dependent on a multiplicity of internal and external factors. Controllable risk factors include smoking, stress, poor oral hygiene and infrequent visits to the Dentist. Non-controllable risk factors include heredity, systemic diseases and age. The genetic component does not cause the disease; however it does make patients more susceptible to emergence of periodontal pathologies or to more serious disease course ${ }^{44}$ Certain pathogens, such as Porphyromonas gingivalis, Tanerella forsythia and Fusobacterium nucleatum, can also influence disease severity. ${ }^{3}$

Stress also contributes to increasing the incidence of PD by creating conditions of resistance to glucocorticoids and increased IL-1, IL-6 and TNF- $\alpha$ production, ${ }^{45}$ caused by a dysfunction of $\mathrm{CD} 11 \mathrm{~b}$ monocytes in response to microbial products. ${ }^{46}$ Stress leads to down regulation of genes that are activated by glucocorticoids and act to suppress the immunoresponse, while up-regulating genes that cause exacerbation of the inflammatory process, both of which are factors that explain the intimate relationship between stress and PD. ${ }^{47}$ Stressed patients tend to adopt habits that worsen the health of their teeth, such as defective oral hygiene, smoking more than average and negative changes to dietary habits. $^{48}$

The relationship between PD and AD can be explained by the action of circulating inflammatory cytokines that stimulate atherogenesis, or by the direct action of pathogenic bacteria that penetrate the circulatory system via the inflamed gingival tissues. One hypothetical model with a biological basis is the suggestion that individuals with cardiac and periodontal diseases have an exacerbated immunoresponse to bacterial infections. ${ }^{49}$ This response is caused by an abnormality of monocytic cell secretory capacity, by which these cells release high levels of proinflammatory mediators, such as PGE-2, IL-1 $\beta$ and TNF- $\alpha$. People who have the hyperinflammatory monocyte phenotype secrete from three to ten times more mediators in response to bacterial lipopolysaccharides, when compared with people who are phenotypically normal. ${ }^{50}$ 
According to Seymour and Steele, ${ }^{51}$ there is evidence that patients with aggressive forms of periodontitis have this hyperinflammatory phenotype. Thus, the interaction between bacterial lipopolysaccharides and the monocytes that release a range of different cytokines is fundamental to initiation and progression of PD and also to its systemic effects, such as atherogenesis and thrombogenesis. Elevated CRP concentrations increase the risk of cardiovascular events by 1.9 times. ${ }^{3}$

In addition to CRP, which has been discussed above, there are other proteins that also react to inflammation in the periodontium. Results for plasma fibrinogen tests, white blood cell counts and von Willebrand factor assays are all elevated in patients with periodontal problems. ${ }^{52}$ Additionally, people who have PD and elevated concentrations of acute phase proteins, such as CRP, fibrinogen, serum amyloid type 1, an adhesion molecules ICAM-1, E-Selectin and VCAM-1, are more likely to develop atherosclerosis and cardiovascular diseases. ${ }^{11}$

Fibrinogen is produced by hepatocytes in response to the action of cytokines, especially IL-6. Plasma fibrinogen concentrations are increased during chronic inflammations and infections, creating a hypercoagulable state. Thrombogenesis is related to atherogenesis and to growth of atherosclerotic plaques. Fibrinogen and fibrin, in turn, interact with monocytes, increasing production of IL- $1 \beta$, which is an important mediator related to PD. ${ }^{53,54}$

According to a study conducted by de Oliveira et al., ${ }^{40}$ the worse a person's oral hygiene, the higher the concentrations of CRP and fibrinogen, and the greater the risk of cardiovascular events. There were differences between groups with good dental hygiene (CRP: $3.07 \mathrm{mg} / \mathrm{L}$ ) and individuals who brushed their teeth less than once per day (CRP: 4.18 $\mathrm{mg} / \mathrm{L} ; \mathrm{P}<0.05$ ); and the same was true of fibrinogen, which was at higher concentrations in the group with poor oral hygiene $(2.86 \mathrm{~g} / \mathrm{L} \times 2.98 \mathrm{~g} / \mathrm{L} ; \mathrm{P}<0.05)$.

While treating PD results in a transitory increase in proinflammatory cytokine levels, which is probably related to manipulation of the inflamed tissues and transitory bacteremia, inflammatory activity normalizes in 24 to 48 hours and, over the long term, if PD responds to treatment then concentrations of these cytokines will reduce. ${ }^{55}$

The NHANES I study ${ }^{56}$ detected a $25 \%$ increase in the relative risk of CAD among patients with periodontitis. Relative risks for angina and for fatal coronary events were 1.5 and 1.9 , respectively. ${ }^{57}$ Periodontal disease is associated with a $19 \%$ increase in the risk of cardiovascular disease and this risk is even higher in the population aged less than 65 years, among whom relative risk is increased by as much as $44 \%{ }^{58}$

Periodontal pathogens colonizing atherosclerotic plaques can be observed throughout the circulatory system. Invasion of the artery wall by Porphyromonas gingivalis, for example, provokes endothelial expression of adhesion molecules such as IL-6, IL-1 $\beta$ and TNF- $\alpha$. There is then recruitment of monocytes, and increase in expression of endothelial adhesion molecules and increased uptake of lipids by macrophages. ${ }^{41}$ The bacterial agents most frequently identified in atherosclerotic plaques are Porphyromonas gingivalis (32\%); Aggregatibacter actinomycetencomitans (4\%); Prevotella intermédia (20\%), and Treponema denticola (32\%). Administration of systemic antibiotics to patients with periodontitis resulted in reductions in the levels of systemic markers of inflammation. ${ }^{40} \mathrm{~A}$ review of the results from around 90 thousand patients with periodontitis found that relative risk of CVD was $120 \%$ higher in the affected group, when compared with controls. ${ }^{59}$ According to Hung et al. ${ }^{60}$ periodontitis increases the relative risk of PAD by 1.4 to 2.6 times. According to Balan, ${ }^{3} \mathrm{PD}$ can be considered a weak independent risk factor for CVD, with relative risk around 24 to $35 \%$ higher than normal.

However, according to some authors the relationship between periodontitis and CVDs is still unproven. ${ }^{61}$ Confounding factors prevent clear conclusions from being drawn because both $\mathrm{AD}$ and PD Share common risk factors. One example of this is smoking, which increases the incidence both of $\mathrm{PD}$ and of $\mathrm{AD}$ and could give a false impression that atherosclerosis increases the incidence of periodontitis or vice-versa. ${ }^{62}$

Implementation of a strategy to combat the processes of disease in teeth and their repercussions on other body systems will demand a change in habits and customs, which may imply increased investment in preservation of natural teeth. Health professionals will therefore have to illustrate to the population the importance of preserving natural teeth even if this demands greater care and expenditure on each individual person's health. In order to achieve this, health services must implement strategies designed to facilitate access to dental care, in particular for less privileged populations, among which the prevalence of periodontal diseases is higher. It is sometimes difficult to deal with this paradigm and it is even possible to find authors publishing in the medical 
literature who argue against preservation of natural teeth on the basis that someone who has no teeth also has no PD and is therefore at lower risk of the systemic repercussions of periodontitis. Working from the same principal, perhaps they will also begin to recommend removing kidneys to avoid kidney stones or removing the heart to avoid myocardial infarction.

\section{REFERENCES}

1. Dumitrescu AL. Influence of periodontal disease on cardiovascular diseases. Rom J Intern Med. 2005;43(1-2):9-21.

2. Bongard V, Cambou JP, Lezorovcz A, et al. Comparison of cardiovascular risk factors and drug use in 14,544 French patients with a history of myocardial infarction, ischaemic stroke and/ or peripheral arterial disease. Eur J Cardiovasc Prev Rehabil. 2004;11(5):394-402.

3. Balan H. Do cardio-vascular and periodontal diseases have a close, causal relationship? Rom J Intern Med. 2010;48(2):121-9.

4. World Health Organization - WHO. NCD Brazil profiles. Genebra: World Health Organization - WHO; 2011.

5. World Health Statistics [site na Internet]. 2013. Genebra: World Heath Organization - WHO. [atualizado 2014; citado 2013 maio 29]. www.who.int

6. Fischer RG. Doença periodontal e doenças cardiovasculares. In: Paiva JS, Almeida RV, editors. Periodontia: a atuação clínica baseada em evidências científicas. São Paulo: Artes Médicas; 2005. p. 285-9.

7. Schmidt MI, Duncan BB, Azevedo e Silva G, et al. Chronic noncommunicable diseases in Brazil: burden and current challenges. Lancet. 2011;377(9781):1949-61. http://dx.doi.org/10.1016/ S0140-6736(11)60135-9. PMid:21561658

8. Paizan ML, Martin JFV. Association between periodontal disease, cardiovascular disease and hypertension. Rev Bras Hipertens. 2009;16(3):183-5.

9. Almeida CSL, Dias LZS. The importance of inflammatory citokynes in the causal relationship between periodontal and cardiovascular diseases. Rev ABO Nac. 2008;16(5):294-8.

10. Jorge PAR. Endotélio, lípides e aterosclerose. Arq Bras Cardiol. 1997;68(2):129-34. PMid:9433841.

11. Ramírez JH, Arce RM, Contreras A. Periodontal treatment effects on endothelial function and cardiovascular disease biomarkers in subjects with chronic periodontitis: protocol for a randomized clinical trial. Trials. 2011;12(1):46. http://dx.doi.org/10.1186/17456215-12-46. PMid:21324167

12. Napoli C, Glass CK, Witztum JL, Deutsch R, D'Armiento FP, Palinski W. Influence of maternal hypercholesterolaemia during pregnancy on progression of early atherosclerotic lesions in childhood: Fate of Early Lesions in Children (FELIC) study. Lancet. 1999;354(9186):1234-41. http://dx.doi.org/10.1016/S01406736(99)02131-5. PMid:10520631

13. Teixeira J, Morado Pinho M. Association between periodontitis and stroke (CVA). Rev Port Estomatol Med Dent Cir Maxilofac. 2011;52(2):115-21.

14. Nguyen TT, Liao Y, Gildengorin G, Tsoh J, Bui-Tong N, McPhee SJ. Cardiovascular risk factors and knowledge of symptoms among
Vietnamese Americans. J Gen Intern Med. 2009;24(2):238-43. http://dx.doi.org/10.1007/s11606-008-0889-1. PMid:19089498

15. Hara T, Takamura N, Akashi S, et al. Evaluation of clinical markers of atherosclerosis in young and elderly Japanese adults. Clin Chem Lab Med. 2006;44(7):824-9. http://dx.doi.org/10.1515/ CCLM.2006.149. PMid:16776627

16. Kanoh Y. [Biochemical markers and physiological tests of atherosclerosis-changes and usefulness of markers in anti-atherosclerotic therapy]. Rinsho Byori. 2011;59(1):80-8. PMid:21404587

17. Thompson D, Pepys MB, Wood SP. The physiological structure of human $\mathrm{C}$-reactive protein and its complex with phosphocholine. Structure. 1999;7(2):169-77. http://dx.doi.org/10.1016/S09692126(99)80023-9. PMid:10368284

18. Tillett WS, Francis T. Serological Reactions in Pneumonia with a Non-Protein Somatic Fraction of Pneumococcus. J Exp Med. 1930;52(4):561-71. http://dx.doi.org/10.1084/jem.52.4.561. PMid:19869788

19. Gabay C, Kushner I. Acute-phase proteins and other systemic responses to inflammation. N Engl J Med. 1999;340(6):448-54 http://dx.doi.org/10.1056/NEJM199902113400607.PMid:9971870

20. Pepys MB, Hirschfield GM. C-reactive protein: a critical update. J Clin Invest. 2003;111(12):1805-12. http://dx.doi.org/10.1172/ JCI200318921. PMid:12813013

21. Torzewski M, Rist C, Mortensen RF, et al. C-reactive protein in the arterial intima: role of $\mathrm{C}$-reactive protein receptor-dependent monocyte recruitment in atherogenesis. Arterioscler Thromb Vasc Biol. 2000;20(9):2094-9. http://dx.doi.org/10.1161/01. ATV.20.9.2094. PMid:10978254

22. Volp AC, Alfenas RC, Costa NM, Minim VP, Stringueta PC, Bressan J. [Inflammation biomarkers capacity in predicting the metabolic syndrome]. Arq Bras Endocrinol Metabol. 2008;52(3):537. 49. http://dx.doi.org/10.1590/S0004-27302008000300015. PMid:18506280

23. Torzewski M, Bhakdi S. Complement and atherosclerosis-united to the point of no return? Clin Biochem. 2013;46(1-2):20-5. PMid:23010447

24. Steel DM, Whitehead AS. The major acute phase reactants: $\mathrm{C}$-reactive protein, serum amyloid $\mathrm{P}$ component and serum amyloid A protein. Immunol Today. 1994;15(2):81-8. http://dx.doi. org/10.1016/0167-5699(94)90138-4. PMid:8155266

25. Biasucci LM, Vitelli A, Liuzzo G, et al. Elevated levels of interleukin-6 in unstable angina. Circulation. 1996;94(5):874-7. http://dx.doi.org/10.1161/01.CIR.94.5.874. PMid:8790019

26. Pradhan AD, Manson JE, Rifai N, Buring JE, Ridker PM. C-reactive protein, interleukin 6 , and risk of developing type 2 diabetes mellitus. JAMA. 2001;286(3):327-34. http://dx.doi.org/10.1001/ jama.286.3.327. PMid:11466099

27. Rudd JH, Myers KS, Sanz J, Fayad ZA. Multimodality imaging of atherosclerosis (magnetic resonance imaging/computed tomography/positron emission tomography-computed tomography). Top Magn Reson Imaging. 2007;18(5):379-88. http:// dx.doi.org/10.1097/rmr.0b013e3181598db0. PMid:18025992

28. Casella IB, Presti C, Porta RM, Sabbag CR, Bosch MA, Yamazaki Y A practical protocol to measure common carotid artery intimamedia thickness. Clinics (São Paulo). 2008;63(4):515-20. http:// dx.doi.org/10.1590/S1807-59322008000400017. PMid:18719764

29. de Korte $\mathrm{CL}$, Hansen $\mathrm{HH}$, van der Steen AF. Vascular ultrasound for atherosclerosis imaging. Interface Focus. 2011;1(4):565-75. http://dx.doi.org/10.1098/rsfs.2011.0024. PMid:22866231 
30. Tola M, Yurdakul M, Cumhur T. Combined use of color duplex ultrasonography and B-flow imaging for evaluation of patients with carotid artery stenosis. AJNR Am J Neuroradiol. 2004;25(10):1856-60. PMid:15569764

31. ESAOTE SpA. Discover the extraordinary potential of RF-data Technology, the unexplored side of ultrasound. Geneva: WHO Press; 2009 [citado 2009 abr. 03]. http://www.esaote.com.ar/ media/docs/ProductNews_RF\%20Technology.pdf

32. Ciccone MM, Scicchitano P, Zito A, et al. Correlation between coronary artery disease severity, left ventricular mass index and carotid intima media thickness, assessed by radiofrequency. Cardiovasc Ultrasound. 2011;9(1):32. http://dx.doi. org/10.1186/1476-7120-9-32. PMid:22087814

33. Schreuder FH, Graf M, Hameleers JM, Mess WH, Hoeks AP. Measurement of common carotid artery intima-media thickness in clinical practice: comparison of B-mode and RF-based technique. Ultraschall Med. 2009;30(5):459-65. http://dx.doi. org/10.1055/s-0028-1109187. PMid:19544231

34. Smith SC Jr, Amsterdam E, Balady GJ, et al. Prevention Conference $\mathrm{V}$ : Beyond secondary prevention: identifying the high-risk patient for primary prevention: tests for silent and inducible ischemia: Writing Group II. Circulation. 2000;101(1):E12-6. http://dx.doi. org/10.1161/01.CIR.101.1.e12. PMid:10618317

35. Touboul PJ, Hennerici MG, Meairs S, et al. Mannheim carotid intima-media thickness consensus (2004-2006). An update on behalf of the Advisory Board of the 3rd and 4th Watching the Risk Symposium, 13th and 15th European Stroke Conferences, Mannheim, Germany, 2004, and Brussels, Belgium, 2006. Cerebrovasc Dis. 2007;23(1):75-80. http://dx.doi. org/10.1159/000097034. PMid:17108679

36. Roman MJ, Naqvi TZ, Gardin JM, Gerhard-Herman M, Jaff M, Mohler E, and the American Society of Echocardiography, and the Society for Vascular Medicine and Biology. American society of echocardiography report. Clinical application of noninvasive vascular ultrasound in cardiovascular risk stratification: a report from the American Society of Echocardiography and the Society for Vascular Medicine and Biology. Vasc Med. 2006;11(3):201-11. http://dx.doi.org/10.1177/1358863×06070511. PMid:17288128

37. Gerhard-Herman M, Gardin JM, Jaff M, Mohler E, Roman M, Naqvi TZ, American Society of Echocardiography, Society for Vascular Medicine and Biology. Guidelines for noninvasive vascular laboratory testing: a report from the American Society of Echocardiography and the Society for Vascular Medicine and Biology. Vasc Med. 2006;11(3):183-200. http://dx.doi. org/10.1177/1358863×06070516. PMid:17288127

38. Nanci A, Bosshardt DD. Structure of periodontal tissues in health and disease. Periodontol. 2000;40:11-28.

39. Buhlin K, Gustafsson A, Pockley AG, Frostegård J, Klinge B. Risk factors for cardiovascular disease in patients with periodontitis. Eur Heart J. 2003;24(23):2099-107. http://dx.doi.org/10.1016/j. ehj.2003.09.016. PMid:14643270

40. de Oliveira C, Watt R, Hamer M. Toothbrushing, inflammation, and risk of cardiovascular disease: results from Scottish Health Survey. BMJ. 2010;340(may27 1):c2451. http://dx.doi.org/10.1136/ bmj.c2451. PMid:20508025

41. Chen $Y W, U$ meda $M$, Nagasawa T, et al. Periodontitis may increase the risk of peripheral arterial disease. Eur J Vasc Endovasc Surg. 2008;35(2):153-8. http://dx.doi.org/10.1016/j.ejvs.2007.08.016. PMid:17964192

42. lacopino AM, Cutler CW. Pathophysiological relationships between periodontitis and systemic disease: recent concepts involving serum lipids. J Periodontol. 2000;71(8):1375-84. http:// dx.doi.org/10.1902/jop.2000.71.8.1375. PMid:10972656

43. Mattila KJ, Nieminen MS, Valtonen VV, et al. Association between dental health and acute myocardial infarction. BMJ. 1989;298(6676):779-81. http://dx.doi.org/10.1136/ bmj.298.6676.779. PMid:2496855

44. Newman MG, Takei HH, Klokkevold, PR. Carranza FA, Carranza periodontia clínica. Rio de Janeiro: Elsevier; 2006

45. Powell CA, Bannister SR, Mackey SA, Maller SC, McDonnell HT, Deas DE. Periodontal wound healing with and without plateletrich plasma: histologic observations and assessment of flap tensile strength. J Periodontol. 2009;80(6):985-92. http://dx.doi. org/10.1902/jop.2009.080626. PMid:19485830

46. Bailey MT, Kinsey SG, Padgett DA, Sheridan JF, Leblebicioglu B. Social stress enhances IL-1beta and TNF-alpha production by Porphyromonas gingivalis lipopolysaccharide-stimulated CD11b+ cells. Physiol Behav. 2009;98(3):351-8. http://dx.doi.org/10.1016/j. physbeh.2009.06.013. PMid:19560480

47. Hilgert JB, Hugo FN, Bandeira DR, Bozzetti MC. Stress, cortisol, and periodontitis in a population aged 50 years and over. J Dent Res. 2006;85(4):324-8. http://dx.doi. org/10.1177/154405910608500408. PMid:16567552

48. Deinzer R, Förster P, Fuck L, Herforth A, Stiller-Winkler R, Idel H. Increase of crevicular interleukin 1 beta under academic stress at experimental gingivitis sites and at sites of perfect oral hygiene. J Clin Periodontol. 1999;26(1):1-8. http://dx.doi.org/10.1034/j.1600051X.1999.260101.x. PMid:9923503

49. Friedewald VE, Kornman KS, Beck JD, et al, and the American Journal of Cardiology, and the Journal of Periodontology. The American Journal of Cardiology and Journal of Periodontology Editors' Consensus: periodontitis and atherosclerotic cardiovascular disease. Am J Cardiol. 2009;104(1):59-68. http:// dx.doi.org/10.1016/j.amjcard.2009.05.002. PMid:19576322

50. BeckJD, Eke P, Heiss G, et al. Periodontal disease and coronary heart disease: a reappraisal of the exposure. Circulation. 2005;112(1):1924. http://dx.doi.org/10.1161/CIRCULATIONAHA.104.511998. PMid: 15983248

51. Seymour RA, Steele JG. Is there a link between periodontal disease and coronary heart disease? Br Dent J. 1998;184(1):33-8. http:// dx.doi.org/10.1038/sj.bdj.4809536. PMid:9479812

52. Mattila $K$, Vesanen $M$, Valtonen $V$, et al. Effect of treating periodontitis on C-reactive protein levels: a pilot study. BMC Infect Dis. 2002;2(1):30. http://dx.doi.org/10.1186/1471-2334-230. PMid: 12475397

53. Ge S, Wu YF, Liu TJ, Meng S, Zhao L. [Study of the correlation between moderately and severely chronic periodontitis and coronary heart disease]. Hua Xi Kou Qiang Yi Xue Za Zhi. 2008;26(3):262-6. PMid:18705507

54. Ge S, Wu YF, Liu T], He QM, Zhao L, Meng S. [Correlation between levels of fibrinogen, beta $455 \mathrm{~g} / \mathrm{A}$ fibrinogen gene polymorphism and chronic periodontitis]. Zhonghua Kou Qiang Yi Xue Za Zhi. 2008;43(2):87-91. PMid:18683729

55. Tonetti MS, Van Dyke TE, and the Working group 1 of the joint EFP/AAP workshop. Periodontitis and atherosclerotic cardiovascular disease: consensus report of the Joint EFP/ AAP Workshop on Periodontitis and Systemic Diseases. J Clin Periodontol. 2013;40(Suppl 14):S24-9. http://dx.doi.org/10.1111/ jcpe.12089. PMid:23627332

56. DeStefano F, Anda RF, Kahn HS, Williamson DF, Russell CM. Dental disease and risk of coronary heart disease and mortality. 
BMJ. 1993;306(6879):688-91. http://dx.doi.org/10.1136/ bmj.306.6879.688. PMid:8471920

57. Beck J, Garcia R, Heiss G, Vokonas PS, Offenbacher S. Periodontal disease and cardiovascular disease. J Periodontol. 1996;67(10, Suppl):1123-37. http://dx.doi.org/10.1902/jop.1996.67.10.1123. PMid:8910831

58. Janket SJ, Baird AE, Chuang SK, Jones JA. Meta-analysis of periodontal disease and risk of coronary heart disease and stroke. Oral Surg Oral Med Oral Pathol Oral Radiol Endod. 2003;95(5):559-69. http://dx.doi.org/10.1067/moe.2003.107. PMid:12738947

59. Thomopoulos C, Tsioufis C, Soldatos N, Kasiakogias A, Stefanadis C. Periodontitis and coronary artery disease: a questioned association between periodontal and vascular plaques. Am J Cardiovasc Dis. 2011;1(1):76-83. PMid:22254188

60. Hung HC, Willett W, Merchant A, Rosner BA, Ascherio A, Joshipura KJ. Oral health and peripheral arterial disease. Circulation. 2003;107(8):1152-7. http://dx.doi.org/10.1161/01. CIR.0000051456.68470.C8. PMid:12615794

61. Lane JS, Vittinghoff E, Lane KT, Hiramoto JS, Messina LM. Risk factors for premature peripheral vascular disease: results for the National Health and Nutritional Survey, 1999-2002. J Vasc Surg. 2006;44(2):319-24, discussion 324-5. http://dx.doi.org/10.1016/j. jvs.2006.04.015. PMid:16890861

62. Genco R, Offenbacher S, Beck J. Periodontal disease and cardiovascular disease: epidemiology and possible mechanisms. J Am Dent Assoc. 2002;133(1, Suppl):14S-22S. http://dx.doi. org/10.14219/jada.archive.2002.0375. PMid:12085720
Correspondence Jeferson Freitas Toregean Rua Dom Pedro II, 2359

CEP 85812-120 - Cascavel (PR), Brazi Fone: +55 (45) 3225-1288

E-mail: jeferson@institutovascular.com.br

Author information

JFT - Vascular surgeon, TSBACV, Assistant professor of Vascular Surgery at Universidade Estadual do Oeste do Paraná (UNIOESTE) and Faculdade Assis Gurgacz (FAG). MSc in Biosciences and Health from UNIOESTE.

CAN and PON - MScs and PhDs in Periodontology from Universidade Estadual Paulista Júlio de Mesquita Filho (UNESP); Full professors of Periodontology at Universidade Estadual do Oeste do Paraná (UNIOESTE)

KAMT - Nutritionist. Biological Sciences student at Universidade Estadual do Oeste do Paraná (UNIOESTE). MSc in Nutrition from Universidade Estadual de Maringá (UEM).

Author contributions Conception and design: JFT, CAN Analysis and interpretation: JFT, CAN, KAMT, PON Data collection: JFT, CAN, PON Writing the article: JFT, CAN Critical revision of the article: CAN, PON Final approval of the article*: JFT, CAN, KAMT, PON Statistical analysis: JFT, PON Overall responsibility: JFT, CAN Financial support: None.

*All authors have read and approved of the final version of the article submitted to I Vasc Bras. 